\title{
Pemberdayaan kelompok tani tambak garam bulcin mandiri di Desa Bulu Cindea Kecamatan Bungoro Kabupaten Pangkep
}

\author{
Abd. Rasyid Jalil' ${ }^{1}$, Rahmi ${ }^{* 2}$, Abdul Rakhim Nanda ${ }^{\circledR 2}$, Rahmat Muhammad ${ }^{1}, \&$ Ilham Jaya1 \\ 1Universitas Hasanuddin \\ 2Universitas Muhammadiyah Makassar \\ *rahmiperikanan@unismuh.ac.id
}

\begin{abstract}
Abstrak. Pengembangan potensi desa Bulu Cindea khususnya garam di Kabuaten Pangkep perlu terus diupayakan agar dapat meningkatkan ekonomi masyarakat petani khususnya garam. Program pengabdian ini bertujuan menghasilkan garam konsumsi beryodium dengan inovasi peralatan garam konsumsi dalam meningkatkan produksi dan produktivitas garam dengan biaya yang murah dan dapat berkelanjutan. Metode yang digunakan melalui FGD dan bimbingan teknis pemanfaatan peralatan dengan daya rendah sesuai dengan kapasitas listrik rumah tangga bagi kelompok petani garam. Kegiatan pengabdian ini akan memberikan manfaat kepada berbagai pihak, diantaranya bagi kelompok masyarakat desa yang terlibat dalam pengabdian, bagi perguruan tinggi dan bagi aparat pemerintah desa. Khalayak sasaran kegiatan pengabdian ini adalah kelompok petani garam desa Bulu Cindea. Setelah kegiatan pengabdian ini dilaksanakan, terjadi perubahan perilaku melalui pemahaman kelompok mitra akan kualitas garam konsumsi yang lebih baik. Hasil post-test memperlihatkan pemahaman kelompok peserta kegiatan yang mencapai $82,5 \%$. Perlunya dilakukan pemberdayaan masyarakat lebih lanjut dalam membangun industri pengolahan garam beryodium untuk meningkatkan kesejahteraan dan kesehatan masyarakat.
\end{abstract}

Kata kunci: garam konsumsi, bulcin mandiri, olahan garam

\begin{abstract}
The development of Bulu Cindea village's potential, especially salt in Pangkep Regency, needs to be continuously pursued to improve farming community's economy, especially salt. This service program aims to produce iodized salt consumption by innovating consumption salt equipment to increase salt production and productivity at a low cost and sustainable manner. Through FGDs and technical guidance on the utilization of low power equipment, by metthos used was following with the salt farmer group's household electricity capacity. This service activity will benefits various parties, including village community groups involved in community service, universities, and village government officials. The target audience for this service activity is the group of salt farmers in Bulu Cindea village. After this service activity was carried out, there was a change in behaviour through the understanding of the partner group about the better quality of consumption salt. The post-test results showed that the groups understanding of the activity participants reached $82.5 \%$. The need for further community empowerment in building an iodized salt processing industry improves public welfare and health.
\end{abstract}

Keywords: consumption salt, bulcin mandiri, processed salt

To cite this article: Jalil, A. R., Rahmi, A. R. Nanda., R. Muhammad., \& I. Jaya. 2020 Pemberdayaan kelompok tani tambak garam bulcin mandiri di Desa Bulu Cindea Kecamatan Bungoro Kabupaten Pangkep. Unri Conference Series: Community Engagement 2: 31-37. https://doi.org/10.31258/unricsce.2.31-37

(C) 2020 Authors

Peer-review under responsibility of the organizing committee of Seminar Nasional Pemberdayaan Masyarakat 2020 


\section{PENDAHULUAN}

Kabupaten Pangkajene dan Kepulauan terletak di bagian barat dari Provinsi Sulawesi Selatan, dengan Ibukota Pangkajene dan sebagai pusat pelayanan wilayah bagi Kabupaten Pangkajene dan Kepulauan, selain itu karena letaknya yang sangat strategis dekat dengan Ibukota Provinsi Sulawesi Selatan. Luas wilayah Kabupaten Pangkajene dan Kepulauan (Pangkep) terdiri dari dua belas kecamatan salah satunya Kecamatan Bungoro yang terdiri dari delapan Desa/Kelurahan. Desa Bulu Cindea merupakan salah satu dari desa di kecamatan ini yang memiliki empat dusun. Masyarakat Desa Bulu Cindea berjumlah sekitar 5.240 orang di empat dusun. Perbandingan jenis kelaminnya sendiri tidak terlalu berbeda, yaitu laki-laki sebanyak 2.589 orang dan perempuan 2.651 orang. Dengan jumlah kartu keluarga sebanyak 1.521.

Penduduk Desa Bulu Cindea umumnya mengandalkan bidang perikanan (tambak) serta nelayan sebagai tulang punggung ekonomi desa, yang terdiri dari lahan persawahan, tanah tambak, selain itu juga banyak warga yang berpotensi sebagai nelayan. Pengelolaan potensi unggulan desa seperti perikanan serta peternakan hanya dilakukan dalam skala terbatas atau dalam skala rumah tangga. Tidak ada investasi besar dalam pengelolaan tersebut sehingga produktivitasnya juga terbatas. Potensi perikanan juga sebenarnya dapat dikembangkan sehubung tersedianya media budidaya ikan berupa Bandeng, Mujair, Udang Windu dan Vaname tetapi potensi tersebut belum dikelola secara profesional (DKP Kabupaten Pangkep, 2016). Potensi lainnya sehubungan dengan potensi ekonomi desa yaitu pembuatan garam yang banyak dilakukan di Dusun Jollo.

Program-program prioritas yang terdapat dalam RPJMD Kabupaten Pangkep diharapkan dapat menyelesaikan berbagai permasalahan yang ada di Kecamatan Bungoro khususnya di Desa Bulu Cindea. Salah satu permasalahan yang ada adalah pengolahan garam rakyat. Kualitas garam yang dihasilkan dari Kabupaten Pangkep merupakan garam kualitas konsumsi dengan kandungan $\mathrm{NaCl}$ 78-86\% (Mustakim et al., 2019). Kondisi kualitas garam tersebut masih rendah, dimana garam konsumsi bermutu tinggi memiliki kandungan $\mathrm{NaCl} 97 \%$,kadar air dibawah 0,05\%, warna putih bersih sedangkan garam konsumsi mutu rendah memiliki kadar $\mathrm{NaCl}$ 90-94,7\% dan kadar air 3-7\% (Rusiyanto, et al., ( 2013).

Salah satu faktor yang mempengaruhi rendahnya kualitas produk garam adalah rendahnya produktivitas, kualitas garam rakyat, faktor cuaca, tidak memadainya teknologi, kurangnya sarana dan prasarana, serta rendahnya kemampuan pemasaran dan jalur distribusi yang dikuasai oleh pedagang. Rendahnya kualitas garam mengakibatkan harga yang diterima petambak garam menurun, sehingga akan berpengaruh terhadap kesejahteraan petambak garam (Rindayani, 2013). Hal ini didukung oleh minimnya keterampilan masyarakat desa dalam memanfaatkan teknologi tepat guna untuk pengembangan hasil laut khususnya garam, juga pemahaman terhadap rendahnya kualitas produk garam, sehingga berefek kepada nilai jual yang rendah. Hal tersebut juga dialami oleh petani garam di Desa Bulu Cindea. Guna mengatasi permasalahan prioritas di desa Bulu Cindea dilakukan melalui pengembangan usaha bidang perikanan untuk meningkatkan taraf kehidupan ekonomi masyarakat serta pemberdayaan masyarakat petani garam. Sejauh ini keterlibatan kelompok petani garam dalam pengolahan garam menjadi garam konsumsi dengan kualitas yang lebih baik masih sangat minim, Padahal bila kualitas garam konsumsi petani tambak baik, maka harga yang diterima oleh petani juga akan lebih tinggi, tentu saja hal ini akan terwujud dengan pemanfaatan iptek yang lebih baik.

Untuk menyelesaikan permasalahan pemanfaatan iptek yang rendah di masyarakat desa Bulu Cindea Kabupaten Pangkep, maka perlu adanya peningkatan penguasaan, pemanfaatan sumber daya alam setempat. Oleh karena itu terlebih dahulu mengkaji kondisi alam sekitar melalui Focus Group Discussion (FGD). Identifikasi permasalahan dimasyarakat saat ini masih tetap dilakukan dalam menentukan tindakan aksi partisipatif sesuai dengan kondisi masyarakat petani garam di desa Bulu Cindea.

\section{METODE PENERAPAN}

Pendekatan partisipatif digunakan dengan keterlibatan masyarakat dalam keseluruhan fase prosesnya (Makosky et al., 2010). Sejalan dengan Fletcher et al., (2015) menjelaskan bagaimana pelibatan masyarakat dalam mobilisasi pengetahuan (iptek) dapat menjadi tolak ukur dalam melihat realitas kehidupan di masyarakat. Berdasarkan kepada referensi yang ada, sehingga digunakanlah pendekatan partisipatorif dalam pelaksanaan kegiatan pengabdian ini. Metode penerapan kegiatan yang dilaksanakan dalam program pengabdian di Desa Bulu Cindea, Kecamatan Bungoro Kabupaten Pangkep di tahun 2020, dapat dilihat pada Tabel 1 dibawah ini. 
Tabel 1. Metode Penerapan

\begin{tabular}{cll}
\hline No & \multicolumn{1}{c}{ Kegiatan } & \multicolumn{1}{c}{ Metode } \\
\hline 1. & Penguatan kelompok usaha garam & $\begin{array}{l}\text { Pelatihan manajemen usaha dan } \\
\text { keuangan }\end{array}$ \\
\hline 2. & $\begin{array}{l}\text { Penggunaan teknologi tepat guna dalam meningkatkan } \\
\text { kualitas garam rakyat }\end{array}$ & $\begin{array}{l}\text { Pembuatan peralatan bantu produksi } \\
\text { garam } \\
\end{array}$ \\
\hline 3. & Pengelolaan garam rakyat menuju garam konsumsi & Maintenance \\
\hline & & $\begin{array}{l}\text { Pelatihan diversifikasi produk } \\
\text { Pengurusan SNI dan Halal }\end{array}$ \\
& & Perluasan jejaring Pemasaran \\
\hline
\end{tabular}

Metode kegiatan menggunakan Focus Group Discussion (FGD), metode ini gunakan karena berbagai kelebihan dalam memberikan kemudahan guna mendapatkan keterbukaan data dari peserta denga berbagai permasalahan yang ada (Masadeh, 2012), dan metode ini menjadi populer digunakan dalam pengabdian saat ini (Bennet et al., 2017). Penggunaan metode FGD oleh tim dipakai secara bergantian, metode ini dilakukan dengan penyampaian konsep tentang pengelolaan garam rakyat menuju garam konsumsi dengan menghadirkan pakar Garam dari Universitas Hasanuddin Dr. Abduh Ibnu Hajar, S.Pi., M.Si. Penggunaan metode ceramah dilakukan dengan menggunakan LCD yang dilengkapi dengan power point yang menarik minat masyarakat. Penggunaan media ini dimaksudkan agar peserta pelatihan lebih mudah memahami tentang produksi garam konsumsi.

Setelah pemahaman materi melalui metode ceramah dilanjutkan dengan pembuatan garam konsumsi beryodium berupa garam halus dan garam meja dengan melibatkan mahasiswa dan masyarakat yang terdapat di desa bulu cindea. Mahasiswa ini akan melakukan pendampingan pada masyarakat desa hingga praktek pembuatan garam tersebut berakhir, serta ikut mendampingi tim pengabdian saat turun ke lapangan.

\section{Alat Ukur Ketercapaian}

Alat ukur ketercapaian kegiatan pengabdian kepada masyarakat ini adalah minimal $50 \%$ peserta pelatihan mengalami peningkatan pemahaman mengenai pembuatan garam konsumsi dan garam meja yang diukur melalui pre-test dan post-test akan diberikan sebelum dan setelah pemberian materi.

\section{HASIL DAN KETERCAPAIAN SASARAN}

Pengabdian masyarakat ini telah dilakukan pada bulan Agustus 2020. Pengabdian ini memberikan manfaat bagi masyarakat di desa Bulu Cindea dari aspek permasalahan sebelum pengabdian ini dilakukan. Kegiatan pengabdian diawali dengan FGD bersama pakar garam yang dilakukan bersama masyarakat petani garam.
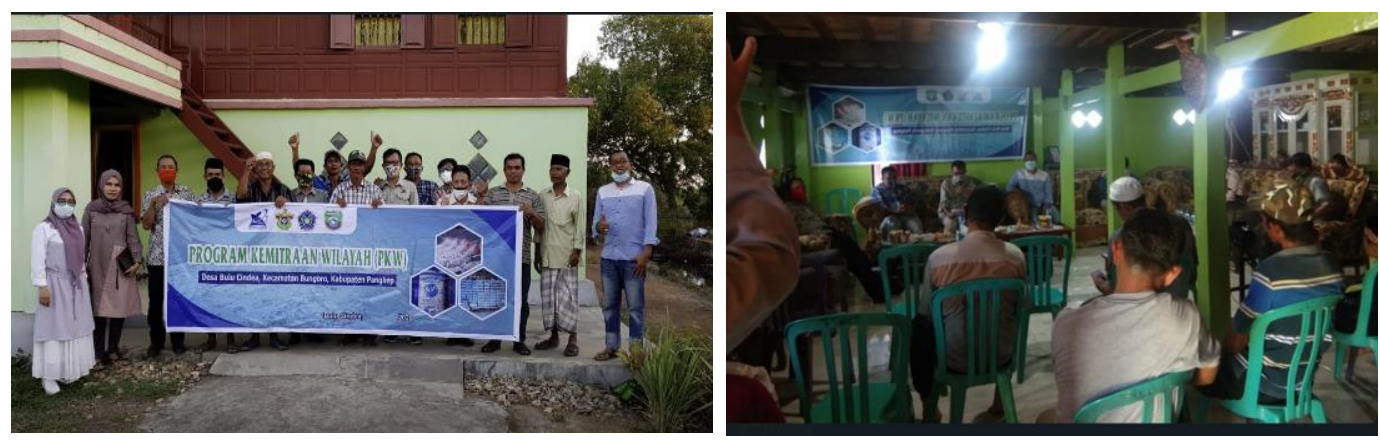

Gambar 1. Kegiatan Focus Group Discussion

Setelah tahapan pemberian materi dilakukan, masyarakat dibagi menjadi beberapa kelompok. Setelah pembagian kelompok peserta dari perwakilan tiap kelompok diharapkan dapat mengikuti materi dengan lebih baik diakibatkan pandemi covid-19 sehingga masyarakat dibagi perkelompok untuk meminimalisir interaksi antar warga masyarakat. Antusias masyarakat dalam kegiatan ini diawali dengan antusias mereka dalam 
mendengarkan materi yang diberikan oleh tim pengabdian. Sebelum memberikan materi peserta di harapkan dapat mengisi pre-test untuk melihat pengetahuan para peserta sebelum diberikan materi, dan setelah kegiatan berlangsung para peserta juga akan diberikan post-test dengan tujuan ingin melihat apakah mereka sudah paham dengan materi yang diberikan. Berdasarkan tingkat pengetahuan peserta dari nilai pre-test yang dilakukan kepada 25 orang peserta, masih ada sekitar 20 orang yang menjawab tidak tau dengan pertanyaan terkait bagaimana komposisi yang benar mengenai pembuatan garam konsumsi beryodium. Sebagian besar peserta hanya memberi perkiraan komposisi tanpa aturan yang jelas. Denan materi yang diberikan oleh tim pengabdian, terlihat jelas kelompok peserta lebih memahami bagaimana aturan komposisi yang jelas bagi garam beryodium, sehingga mereka tidak melakukan pencampuran dengan metode perkiraan yang selama ini digunakan.

Untuk memudahkan pelaksanaan kegiatan pengabdian, tim pengabdian memberikan bantuan berupa peralatan industri garam bagi rumah tangga yang memiliki daya listrik 250 watt sesuai dengan daya listrik rumah tangga di desa bulu cindea. Bantuan peralatan tersebut terkait dengan ketersediaan produksi garam di desa Bulu Cindea. Tim pengabdian memberikan bantuan teknologi penghalus garam, pencampur garam dan pengering garam (Gambar 1). Selama ini kendala masyarakat adalah melimpahnya produksi garam di petani tetapi pesanan akan garam meja semakin tinggi, petani tak memiliki peralatan produksi berupa penghalus garam serta pencampur garam. Dengan tersedianya peralatan tersebut, kelompok tani dapat menggunakannya untuk produksi garam meja yang selama ini mengalami kendala. Petani juga menggunakan pengering garam, yang sewaktu-waktu digunakan apabila hasil produksi garam terlalu basah, sehingga dibutuhkan pengering/oven.
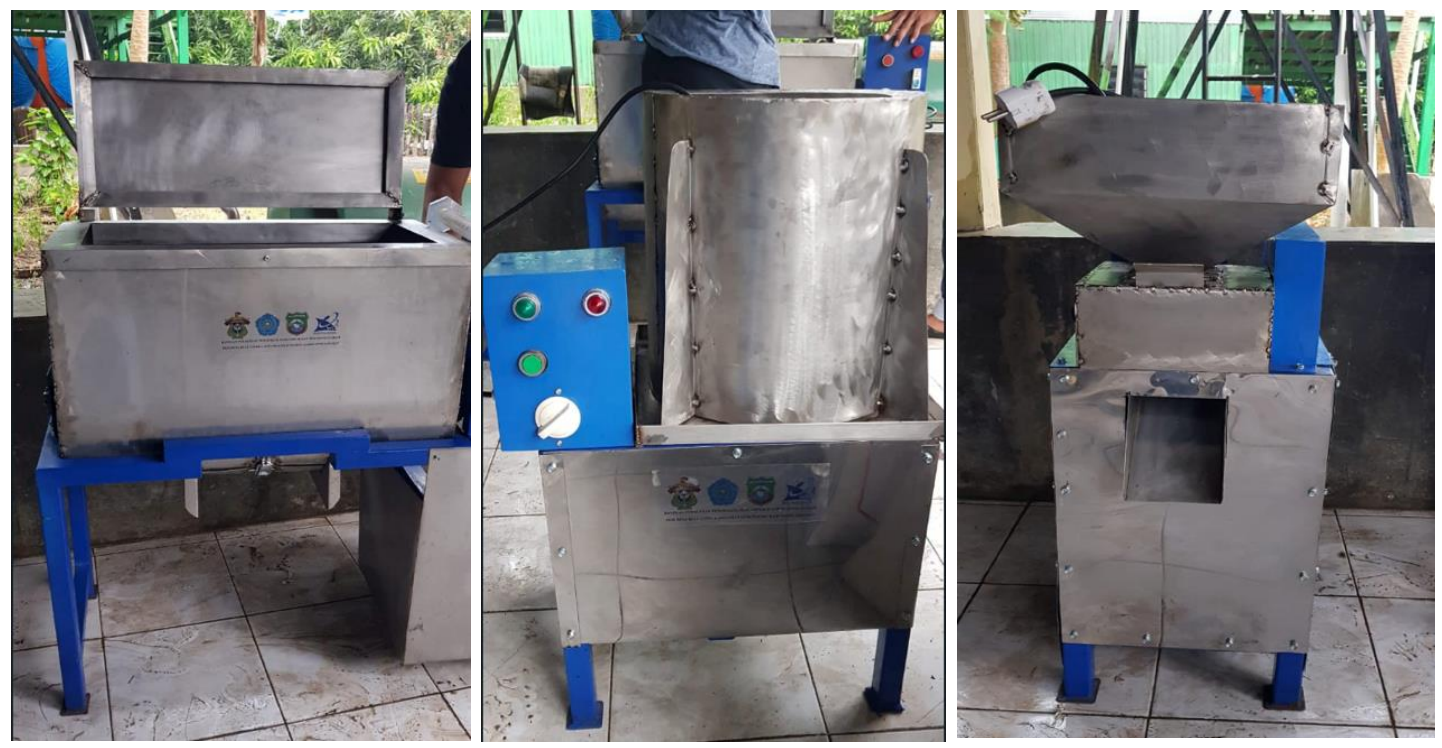

Gambar 2. Bantuan peralatan pencampur garam, pengering garam dan penghalus garam hasil pengembangan tehnologi tim pengabdian masyarakat di Desa Bulu Cindea Kecamatan Bungoro Kabupaten Pangkep

Hasil pengamatan selama kegiatan pengabdian ini diperoleh beberapa hasil positif. Hasil positif tersebut menunjukkan antusiasme yang tinggi terhadap ceramah yang disampaikan oleh tim pengabdian, masyarakat yang terlibat menunjukkan reaksi positif terhadap ketertarikan dalam menghasilkan garam meja, masyarakat mengikuti prosedur pembuatan produk dan melakukan kerja kelompok dengan cukup baik menggunakan peralatan yang didapatkan, (keaktifan juga terlihat dari pertanyaan yang timbul apabila terdapat prosedur yang tidak dimengerti. Pada tahap evaluasi tim pengabdian memberikan soal untuk mereview kembali tujuan dari pengabdian dengan memberikan soal tentang apa dampak penggunaan peralatan tersebut bagi kelompok petani garam. 

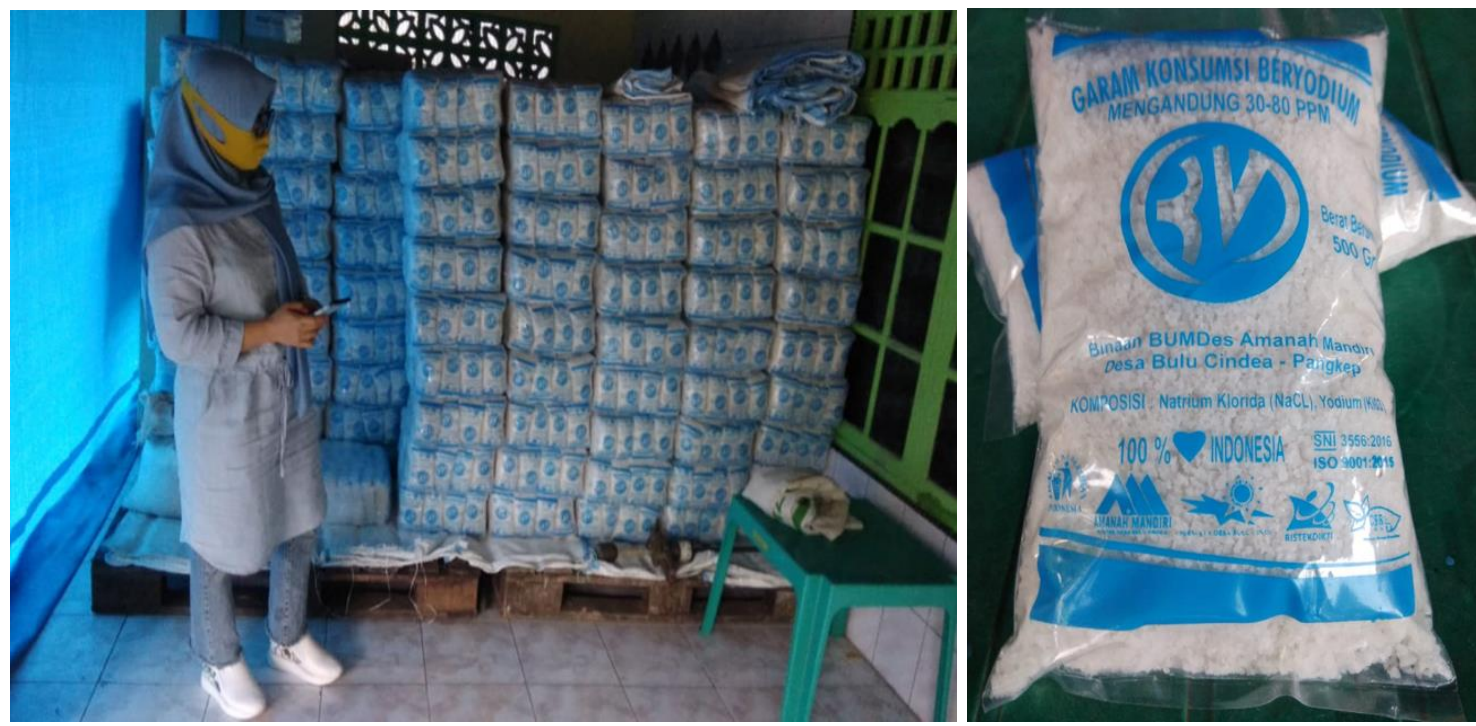

Gambar 3. Hasil produksi garam petani garam BULCIN MANDIRI di desa Bulu Cindea Kecamatan Bungoro Kabupaten Pangkep.

Kegiatan pengabdian ini diharapkan dapat memberikan maanfaat bagi masyarakat petani garam di desa Bulu Cindea, sehingga bisa dijadikan peluang usaha yang baru bagi masyarakat sasaran yaitu kelompok petani garam Bulcin Mandiri. Diharapkan dengan bantuan peralatan ini kelompok masyarakat desa dapat menggunakan dengan lebih baik, sehingga mampu mandatangkan keuntungan secara pribadi maupun secara kelompok bagi masyarakat sekitar desa bulu cindea. Beberapa hasil produksi dari kelompok petani garam sudah diasarkankeluar kota dan mendapat respon positif dari para konsumen diluar kota karena garam yang diproduksi memiliki kualitas yang lebih bagus dibandingkan hasil produksi garm dari daerah lainnya. Hal ini terbukti dari para konsumen luar kota yang melakukan pemesanan berulang kepada para petani garam di desa bulu cindea.

Keunggulan dan kelemahan kegiatan terlihat dari kesesuaiannya dengan kondisi masyarakat di lokasi kegiatan, yang tidak terlepas dari faktor pendukung dan penghambat. Dalam pelaksanaan kegiatan pengabdian, faktor pendukung tersebut diantaranya bagaimana antusias masyarakat dalam mengikuti kegiatan pengabdian cukup baik, sikap ingin tahu serta keinginan dalam mencoba hal baru dan dapat dimanfaatkan oleh para peserta pelatihan dan masyarakat petani garam yang ikut terlibat dalam kegiatan ini. Hal ini tidak lepas dari dukungan pemangku desa terhadap kegiatan pengabdian ini yang senantiasa terlibat langsung dalam berbagai kegiatan tim pengabdian dengan pemberian fasilitas dan tempat bagi tim.

Tingkat kesulitan dalam pelaksanaan kegiatan ini adalah adanya pandemi Covid-19 ini, sehingga tim sulit mengumpulkan masyarakat petani garam yang jumlahnya banyak di Desa Bulu Cindea. Salah satu solusi yang dilakukan oleh tim pengabdian, adalah dengan mengadakan kegaitan ceramah/diskusi perkelompok kegiatan dengan tetap menerapkan protokol kesehatan. Rerata nilai pre-test dan post-test dari kelompok masyarakat dapat ditampilkan pada Gambar 3.

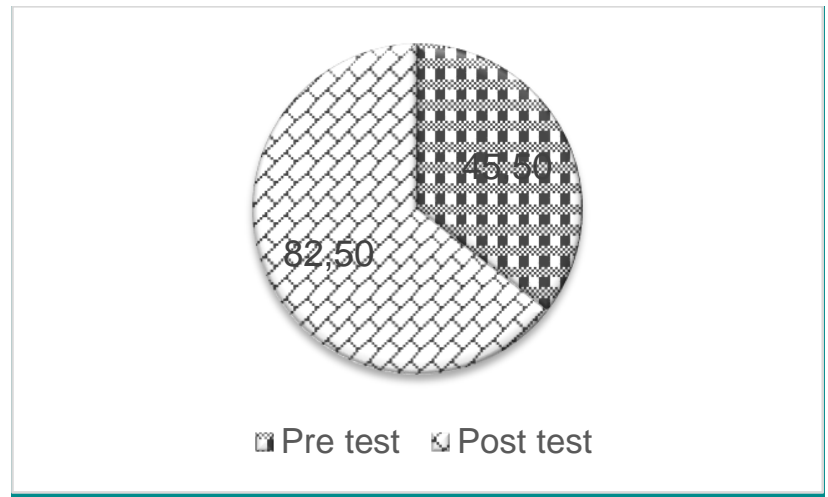

Gambar 3. Rerata nilai pre-test dan post-test pada kegiatan pengabdian di desa Bulu Cindea 
Berdasarkan Gambar 3, terlihat nilai yang jauh berbeda antara pre-test $(45,5 \%)$ dan post test $(82,5 \%)$. Hal ini berarti terjadi peningkatan pengetahuan masyarakat dengan materi yang diberikan pada kegiatan FGD tersebut, peningatan ini terlihat dengan peningkatan nilai post-test. Sehingga dapat disimpulkan bahwa kegiatan ini memberikan nilai positif terhadap pengetahuan masyarakat yang turut serta pada kegiatan ini. Peningkatan pengetahuan bagi masyarakat desa bulu cindea nantinya akan menjadi contoh bagi desa lainnya bagi pemanfaatan garam rakyat. Pelaksanaan proram pengabdian ini dimaksudkan agar masyaraat bulu cindea dapat memanfaatkan hasil produksi garam mereka menjadi lebih baik dan lebih memiliki nilai jual yang tinggi, sehingga diharapkan dapat menjadi stimulus bagi masyarakat lainnya dalam pemanfaatan garam dengan nilai jual tinggi.

\section{KESIMPULAN}

Pengembangan potensi Desa Bulu Cindea khususnya garam di Kabupaten Pangkep perlu terus diupayakan agar dapat meningkatkan ekonomi masyarakat petani khususnya garam. Tim pengabdian melalui kerjasama antara semua pihak melakukan pembinaan dan pembimbingan produksi garam rakyat dengan menggunakan teknologi yang telah tersedia dengan bantuan peralatan yang diberikan sebagai hasil inovasi dari tim. Pelaksanan program pengabdian ini dimaksudkan agar masyarakat dapat memanfaatkan inovasi dan teknologi yang dihasilkan untuk menghasilkan garam dengan kualitas yang lebih baik, sehingga mampu bersaing dengan berbagai hasil garam dari wilayah yang lainnya, disamping itu juga dapat menjadi nilai tambah bagi masyarakat Desa Bulu Cindea, sehingga dapat meningkatkan taraf kehidupan petani khususnya petani garam. Dalam kegiatan ini telah terjadi perubahan perilaku kelompok mitra dalam pemanfaatan teknologi dalam memproduksi garam. Dengan adanya peningkatan kualitas dan kuantitas produksi garam desa Bulu Cindea Kecamatan Bungoro Kabupaten Pangkep.

Beberapa rekomendasi bagi keberhasilan komoditas garam di Kabupaten Pangkep berupa, (1) perlu adanya dukungan fasilitas peningkatan kelembagaan kelompok tani garam, kelembagaan BUMDes yang berkesinambungan, (2)perlunya evaluasi pada program sehingga dapat berjalan secara berkesinambungan, (3) perlu pembinaan berkelanjutan dalam membangkitkan kesadaran dan kemauan masyarakat akan perubahan kehidupan kearah yang lebih baik serta (4)perlu dilakukan pemberdayaan masyarakat lebih lanjut dalam membangun industri pengolahan garam beryodium untuk meningkatkan kesejahteraan dan kesehatan masyarakat.

\section{UCAPAN TERIMA KASIH}

Tim pengabdian kepada masyarakat mengucapkan terima kasih kepada Kementerian Riset Teknologi dan Pendidikan Tinggi atas pendanan program ini melalui Program Kemitraan Wilayah (PKW) 2019-2021 kerjasama Universitas Hasanuddin dan Universitas Muhammadiyah Makassar. Terimakasih juga kepada pemerintah daerah Kabupaten Pangkep khususnya Desa Bulu Cindea dan berbagai pihak yang telah mendukung terlaksananya kegiatan ini.

\section{DAFTAR PUSTAKA}

Bennett, N. J., et al. 2017. Conservation social science: Understanding and integrating human dimensionsto improve conservation. Biological Conservation, 205, 93-108. https://doi.org/10.1016/j.biocon.2016.10.006

Dinas Kelautan dan Perikanan (DKP) Pangkep. 2016. Laporan Akhir program Pengembangan Usaha Garam Rakyat. Satker Dinas Kelautan dan Perikanan Kabupaten Pangkep.

Fletcher, A.J., M. MacPhee, \& G. Dickson. 2015. Doing Participatory Action Research in a Multicase Study: A Methodological Example. International Journal of Qualitative Methods, 14(5), 1-9. https://doi.org/10.1177/1609406915621405

Makosky, C.D., A. S. James, E. Urley, S. Joseph, A. Talawyma, W. S. Choi, K. A. Greiner, \& M. K. Coe. 2010. Using Focus Groups in Community-Based Participatory Research: Challenges and Resolutions. Qualitative Health Research, 20(5), 697-706. https://doi.org/10.1177/1049732310361468

Masadeh, M.A. 2012. Focus Group: Reviews and Practices. International Journal of Applied Science and Technology, 2(10):63-68. http://www.ijastnet.com/journal/index/378

Mustakim, M, M. Kasnir, A. Rauf. 2019. Status Keberlanjutan Usaha garam Industri di Wilayah pesisir Kabupaten Pangkep. DOI: 10.30649/jrkt.v1i1.17. 
Rindayani. 2013. Strategi pemberdayaan masyarakat melalui program pemberdayaan usaha garam rakyat (PUGAR) di Dinas Kelautan dan Perikanan Kabupaten Pamekasan. Jurnal Tani, 1(2), 57-69.

Rusiyanto, Soesilawati, E, Jumaeri. 2013. Penguatan Industri Gram Nasional melalui Perbaikan Teknologi Budidaya dan Diversifikasi Produk. Jurnal Sainteknol, 11(2), 129-142. 